DOI: https://doi.org/10.31933/dijms.v2i4 Received: 23 January 2021, Revised: 7 March 2021, Publish: 15 April 2021

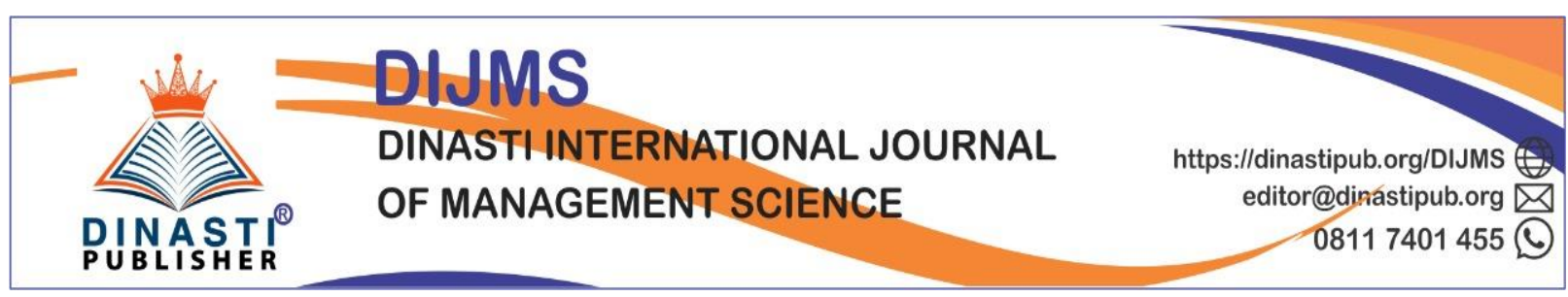

\title{
THE AFFECT OF VIGOR, DEDICATION AND ABSORPTION ON THE EMPLOYEE PERFORMANCE AT PT. MANDIRI UTAMA FINANCE
}

\author{
Ratih Srie Intan Maisyuri ${ }^{1}$, Eny Ariyanto ${ }^{2}$ \\ 1) Universitas Mercu Buana, Jakarta, Indonesia, ratihmaisyuri@gmail.com \\ ${ }^{2)}$ Universitas Mercu Buana, Jakarta, Indonesia, eny_ariyanto@yahoo.com
}

\section{Corresponding Author: Ratih Srie Intan Maisyuri Masrijal}

\begin{abstract}
This research has purpose to revealed those affect from all dimensions of employee engagement, which is vigor, dedication and absorption on the performance of employees at PT. Mandiri Utama Finance. The aims of this research was to discovered an descriptive explanation relates to the vigor, dedication, absorption and also employees performance at PT. Mandiri Utama Finance and it affects towards the performance of employees at PT. Mandiri Utama Finance. The research population was all employees of PT. Mandiri Utama Finance, which amounted of 210 people. Due to the relatively small population, so all the employees were made as respondents (saturated sampling). The data analysis method used multiple linear regression analysis by SPSS (Statistical Package for The Social Sciences) software version 25. The results showed that vigor had a positive and significant affect on employee performance, dedication had a positive and significant affect on employee performance and absorption had a positive and significant affect on employee performance. All above variables has a weak impact with coefficient of determination $\left(R^{2}\right)$ only for $32 \%$.
\end{abstract}

Keywords: Vigor, dedication, absorption, employee performance.

\section{INTRODUCTION}

Human resources plays a crucial partin running all activities at a company. The progress and continuity of the company was influenced by the human resources within. Through making employees as partners in doing business is something that every company needs to do. Besides, the company need to put special attention to the employees where this attention aims to increase the employee performance. High company performance is desired by every company without exception. To create an optimal performance, the employees will strive to achieve thecompany goals and targets in conduct their duties in accordance with the responsibilities that have been given to reach the company goals. The performance that possessed by each of its members is not free from the sense of engaged in where there has asense of attachment and involvement towards work.

According to Robbins \& Coulter (2010), work involvement is how far an employees recognizes their job andnot passive in participating, then considers theirs performances at work as an important matter to respect themselves. Employees who have a high level of work involvement in the job would tends to likes the type of work that they are doing and really care 
about the type of work. For example, the employees who have a high level of work involvement will contribute ideas and suggestions to improve work quality, feel they have no objection in obidient towards thecompany regulations and always support those existing company policies. The Employees who did not have a high level of work involvement will do the opposites.

A finance company or institution is a business entity outside the bank or non-bank financial institution whichprovides loan facilities to customers for certain needs. One of the financing companies which capable to provide motorbike and car installment credit facilities is PT.Mandiri Utama Finance. PT. Mandiri Utama Finance is a finance company under the auspices of one of the largest banks in Indonesia, which is Bank Mandiri.PT.Mandiri Utama Finance as one of the leading finance companies in Indonesia that offers the convenience of obtaining finance ranging from new and second-hand car financing, new motorbikes \& secondhand motorbikes, multipurpose financing, KKB Mandiri and fleet financing.This finance company has two financing systems that customers could choose, namely conventional and sharia (Produk Pembiayaan, 2020).

From the data and the interviews results which conducted to the source person at PT. Mandiri Utama Finance found The issues related to productivity degradation. The resulting performance did not achieved $80 \%$ where this category is set as target category. This has been investigated more further because of the decreased in motivate and enthusiasm of employees due to fatigue and even boredom at work. The Employees are given jobs whichexceed their normally job desks, causing their concentration to decrease and the focus towards work will also disappear. When an employee quit or resigns from the company, so then the company makes a policy regarding the dual position system where the resigned employee's work would be handled by another employee. The energy which possessed by employees when doing work in multiple positions becomes depleted and reduced because it requires them to do the tasks of the dual position. The concentration and seriousness of employees at work were lost so the employees are unable to achieve their job targets optimally. Therefore, the company need to encourage a sense of enthusiasm in employees, a sense of thing which could motivated them and also their concentration in order to improve the employee performance in the company. Consider if the company operates in an uncertain and complex environment, so it is necessary to refine its strategy so it would remain competitive in the business world. In addition, the company were also expected to be able to create an extra value to excel in competition, including in the field of human resources (Nawangsari \& Sutawidjaya, 2019)

Several previous research have shown the variations in the affect of vigor, dedication and absorption towards employee performance. The research results from Javed \& Cheema (2015); Fan \& Cai (2017); Al-dalahmeh et al.(2018); Jaya \& Dawood (2020); Gil et al.(2020) which stated that vigor has a significant affect on performance. The Research which conducted by Lewiuci et al. (2016); Carter et al. (2016); Meilia \& Setyowati (2016), Meswantri \& Awaludin (2018) and Bilal et al. (2019) revealed that dedication has a significant affect on performance. The Research from Rustono \& Akbary (2015); Hanaysha (2016); Yin (2017); Puspa \& Sagala (2018); Winowoda (2018); and Natrajan et al (2019) proved that absorption has a significant affect on employee performance.In contrast, with the research by Joushan et al.(2015); Mahadika et al.(2018); and Witasari \& Gustomo (2020) proved that their research results related to vigor, dedication and absorption did not have an affect on Employee performance.

Through these gaps in the research findings which produced by the researchers and those phenomena which occur, the researchers want to see whether vigor, dedication and absorption have an affect towards the performance and also if these research results related to vigor, dedication, absorption and performance could support the existing theory or not. 


\section{LITERATURE REVIEW Employee Performance}

Basically, the performance has a lot of meaning based on the point of view or opinion from experts. The Performance is the result of a process which referred to and measured over a certain period of time based on predetermined terms or agreements (Edison et al., 2016). According to Mangkunegara (2016) the term of performance comes from the word ofjob performance or actual performance (job performance or actual achievement which reached by someone). The definition of performance is the quality and quantity of work achieved by an employees in carrying out their duties in accordance with the responsibilities which assigned to them.

Koopmans (2014) defines that performance as patterns of behaviour and actions of employees which are relevant to organizational goals. It puts more emphasis on the behaviour patterns and actions of employees than on the results of the behaviour itself. The Performance contains behaviour which under the control of the personal itself, unless those behaviour is influenced by the environment. In this research, theresearchers will use estimation tools which adapted and put forward from Koopmans theory (2014) whereas theperformance is divided into four types, namely task performance, contextual performance, adaptive performance, andcounterproductive work behaviour that consists of 22 questions.

\section{Vigor}

Schaufeli \& Bakker (2004) stated that vigor is characterized by a high level of energy and mental resilience at work, a willingness to put an effort in work and even persistencein facing the problems. The enthusiasm that shown by a person to do its personal job could be seen from the high stamina and energy while working, the willingness to take a serious efforts in doing work and persistence and perseverance in facing the job difficulties.

Vigor which owned by each employee could affect their performance in the company. The Performance is a result of the achievement in a certain task. If the employees carry out their work with high vigor, then they would complete their work optimally and it would have an impact on increasing the performance. Thus it could be concluded that vigor has an affect on employee performance.

This logic is supported by researchers Jaya \& Dawood (2020) who statedthat vigor has a positive and significant affect on employee performance in IT companies at Chennai. Likewise, with the research results from Carter et al. (2016) which stated that vigor has a positive and significant affect on performance. While the research from Winowoda (2018) were explained the same thing that vigor has a significant affect on employee performance. Thus the hypothesis that could be formulated as follows:

H1: Vigor has a positive and significant affect on the employee performance of PT.Mandiri Utama Finance

\section{Dedication}

Schaufeli \& Bakker (2004) argued that dedication is an employees' emotional attachment to their jobs. The dedication describes as the enthusiasm of employees at work and proud of the work done and the company that they worked for and those inspiration and challenges that employee's feel. 
Employees who have high dedication score are strongly enthusiastic and proud of their work and the company. They consider if their job as a challenge which inspires them to do their best so this would lift up theemployee performance in the company. Meanwhile, the employees who has low on dedication score it means that they are unable to do their job properly because they are not enthusiastic and proud of their work and company.

The results from Fauzi \& Ed's research (2016) which argues that dedication has a positive and significant affect on employee performance and has a great contribution to influence was inline with the research results from Fan \& Cai (2017) which shows that dedication has a positive and significant affect on task performance and contextual performance. While the research results from Al-dalahmeh et al. (2018) explained that dedication has significantly contributes to employee performance. Thus the hypothesis that could be formulated as follows:

H2: Dedication has a positive and significant affect on employee performance at a finance company in Indonesia.

\section{Absorption}

Schaufeli \& Bakker (2004) were explained that absorption is employee attachment whichdescribed by employees behaviourwho pay full attention to their work. Absorption describes as the condition of employees who have full concentration and were absorbed in doing their work. When employees do their jobs, they tend to lose track of time so they would feel the time flies so fast which difficult for them to escape from work.

Employees who have high absorption are able to fully concentrate on the job. This capable to have an influence towards their performance in the company. Employees like to get involved in work so the time seems to run fast. Besides, they would find it difficult to get away from their work because they feel immersed in it.

The research results which conducted by Lewiuci et al.(2016) stated that absorption partially has a positive and significant affect on employee performance and has a great contribution affect. Likewise with the research results by Meilia \& Setyowati (2016) which showed that absorption has a positive and significant affect on performance.Meanwhile, the research results which conducted by Meswantri \& Awaludin (2018)explained that absorption is significantly contributedto employee performance. Winowoda (2018) also revealed a similar thing that there has a direct influence of the absorption variable on the employee performance at the Grand Inna Malioboro Hotel Yogyakarta. Thus the hypothesis could be formulated as follows:

H3: Absorption has a positive and significant affect on employee performance at a finance company in Indonesia.

Based on the definition above, the measuring instrument that researcher uses is a measuring tool that adapted and developed by the Utrecht Work Engagement Scale (UWES) (Schaufeli \& Bakker, 2006) consisting of vigor, dedication and absorption. This measuring instrument consists of 17 questions.Vigor is assessed from 6 questions which refer to high energy and endurance, willingness to try more and not easily get tired and persistence in facing difficulties. Dedication is assessed from 5 question items which refer to the significance of the work, the sense of enthusiasm and pride in the work and the sense of being inspired and challenged by the work they do. Absorption is measured by 6 question items which refer to the totality and pleasure at work and it is difficult to get away from work so the time seems pass quickly and forget everything around. 
Table 1. The Compilation of Previous Research Results which Shows the Affects of Vigor, Dedication and Absorption towards Employee Performance

\begin{tabular}{|c|c|c|c|}
\hline Author(s) & Vigor & Dedication & Absorption \\
\hline Jaya \& Dawood (2020) & $\begin{array}{l}\text { Positive, Significant, } \\
\text { Weak }\end{array}$ & $\begin{array}{l}\text { Positive, Significant, } \\
\text { Weak }\end{array}$ & $\begin{array}{l}\text { Positive, Significant, } \\
\text { Weak }\end{array}$ \\
\hline Al-dalahmeh et al. (2018) & $\begin{array}{l}\text { Positive, Significant, } \\
\text { Weak }\end{array}$ & $\begin{array}{l}\text { Positive, Significant, } \\
\text { Very Weak }\end{array}$ & $\begin{array}{l}\text { Positive, Significant, } \\
\text { Very Weak }\end{array}$ \\
\hline Bilal et al. (2018) & $\begin{array}{l}\text { Positive, Significant, } \\
\text { Strong }\end{array}$ & $\begin{array}{l}\text { Positive, Significant, } \\
\text { Strong }\end{array}$ & $\begin{array}{l}\text { Positive, Significant, } \\
\text { Strong }\end{array}$ \\
\hline Carter et al. (2016) & $\begin{array}{l}\text { Positive, Significant, } \\
\text { Very Strong }\end{array}$ & $\begin{array}{l}\text { Positive, Significant, } \\
\text { Very Strong }\end{array}$ & $\begin{array}{l}\text { Positive, Significant, } \\
\text { Very Strong }\end{array}$ \\
\hline Fan \& Cai. (2017) & $\begin{array}{l}\text { Positive, Significant, } \\
\text { Moderate }\end{array}$ & $\begin{array}{l}\text { Positive, Significant, } \\
\text { Moderate }\end{array}$ & $\begin{array}{l}\text { Positive, Significant, } \\
\text { Moderate }\end{array}$ \\
\hline Fauzi \& Sembiring. (2016) & $\begin{array}{l}\text { Positive, Significant, } \\
\text { Moderate }\end{array}$ & $\begin{array}{l}\text { Positive, Significant, } \\
\text { Weak }\end{array}$ & Not Significant \\
\hline Gil et al. (2020) & $\begin{array}{l}\text { Positive, Significant, } \\
\text { Very Strong }\end{array}$ & $\begin{array}{l}\text { Positive, Significant, } \\
\text { Very Strong }\end{array}$ & $\begin{array}{l}\text { Positive, Significant, } \\
\text { Very Strong }\end{array}$ \\
\hline Hanaysha. (2016) & $\begin{array}{l}\text { Positive, Significant, } \\
\text { Very Weak }\end{array}$ & $\begin{array}{l}\text { Positive, Significant, } \\
\text { Strong }\end{array}$ & $\begin{array}{l}\text { Positive, Significant, } \\
\text { Very Weak }\end{array}$ \\
\hline Javed \& Cheema (2015) & $\begin{array}{l}\text { Positive, Significant, } \\
\text { Moderate }\end{array}$ & $\begin{array}{l}\text { Positive, Significant, } \\
\text { Very Strong }\end{array}$ & $\begin{array}{l}\text { Positive, Significant, } \\
\text { Very Strong }\end{array}$ \\
\hline Joushan et al. (2015) & Not Significant & Not Significant & Not Significant \\
\hline Kapil \& Rastogi (2017) & $\begin{array}{l}\text { Positive, Significant, } \\
\text { Weak }\end{array}$ & $\begin{array}{l}\text { Positive, Significant, } \\
\text { Weak }\end{array}$ & $\begin{array}{l}\text { Positive, Significant, } \\
\text { Weak }\end{array}$ \\
\hline Lewiuci \& Mustamu. (2016) & $\begin{array}{l}\text { Positive, Significant, } \\
\text { Weak }\end{array}$ & $\begin{array}{l}\text { Positive, Significant, } \\
\text { Weak }\end{array}$ & $\begin{array}{l}\text { Positive, Significant, } \\
\text { Weak }\end{array}$ \\
\hline Mahadika \& Hadi (2018) & Not Significant & Not Significant & Not Significant \\
\hline Meilia \& Setyowati (2016) & $\begin{array}{l}\text { Positive, Significant, } \\
\text { Weak }\end{array}$ & $\begin{array}{l}\text { Positive, Significant, } \\
\text { Weak }\end{array}$ & $\begin{array}{l}\text { Positive, Significant, } \\
\text { Weak }\end{array}$ \\
\hline Meswantri \& Awaludin (2018) & $\begin{array}{l}\text { Pengaruh Kuat, Positif } \\
\text { Signifikan }\end{array}$ & $\begin{array}{l}\text { Pengaruh Kuat, Positif } \\
\text { Signifikan }\end{array}$ & $\begin{array}{l}\text { Pengaruh Kuat, Positif } \\
\text { Signifikan }\end{array}$ \\
\hline Natrajan et al. (2019) & $\begin{array}{l}\text { Positive, Significant, } \\
\text { Weak }\end{array}$ & $\begin{array}{l}\text { Positive, Significant, } \\
\text { Weak }\end{array}$ & $\begin{array}{l}\text { Positive, Significant, } \\
\text { Weak }\end{array}$ \\
\hline Puspa \& Sagala (2018) & $\begin{array}{l}\text { Positive, Significant, } \\
\text { Weak }\end{array}$ & $\begin{array}{l}\text { Positive, Significant, } \\
\text { Weak }\end{array}$ & $\begin{array}{l}\text { Positive, Significant, } \\
\text { Weak }\end{array}$ \\
\hline Rustono \& Akbary (2015) & $\begin{array}{l}\text { Positive, Significant, } \\
\text { Weak }\end{array}$ & $\begin{array}{l}\text { Positive, Significant, } \\
\text { Weak }\end{array}$ & $\begin{array}{l}\text { Positive, Significant, } \\
\text { Weak }\end{array}$ \\
\hline Sim \& Siswono (2016) & $\begin{array}{l}\text { Positive, Significant, } \\
\text { Weak }\end{array}$ & $\begin{array}{l}\text { Positive, Significant, } \\
\text { Weak }\end{array}$ & $\begin{array}{l}\text { Positive, Significant, } \\
\text { Weak }\end{array}$ \\
\hline Winowoda (2018) & $\begin{array}{l}\text { Positive, Significant, } \\
\text { Strong }\end{array}$ & $\begin{array}{l}\text { Positive, Significant, } \\
\text { Strong }\end{array}$ & $\begin{array}{l}\text { Positive, Significant, } \\
\text { Strong }\end{array}$ \\
\hline Witasari \& Gustomo (2020) & Not Significant & Not Significant & Not Significant \\
\hline Yin (2017) & $\begin{array}{l}\text { Positive, Significant, } \\
\text { Weak }\end{array}$ & $\begin{array}{l}\text { Positive, Significant, } \\
\text { Weak }\end{array}$ & $\begin{array}{l}\text { Positive, Significant, } \\
\text { Weak }\end{array}$ \\
\hline
\end{tabular}

\section{Theoretical Framework and Hypothesis}

According to the description above, the conceptual framework which could be drawn as follows: 


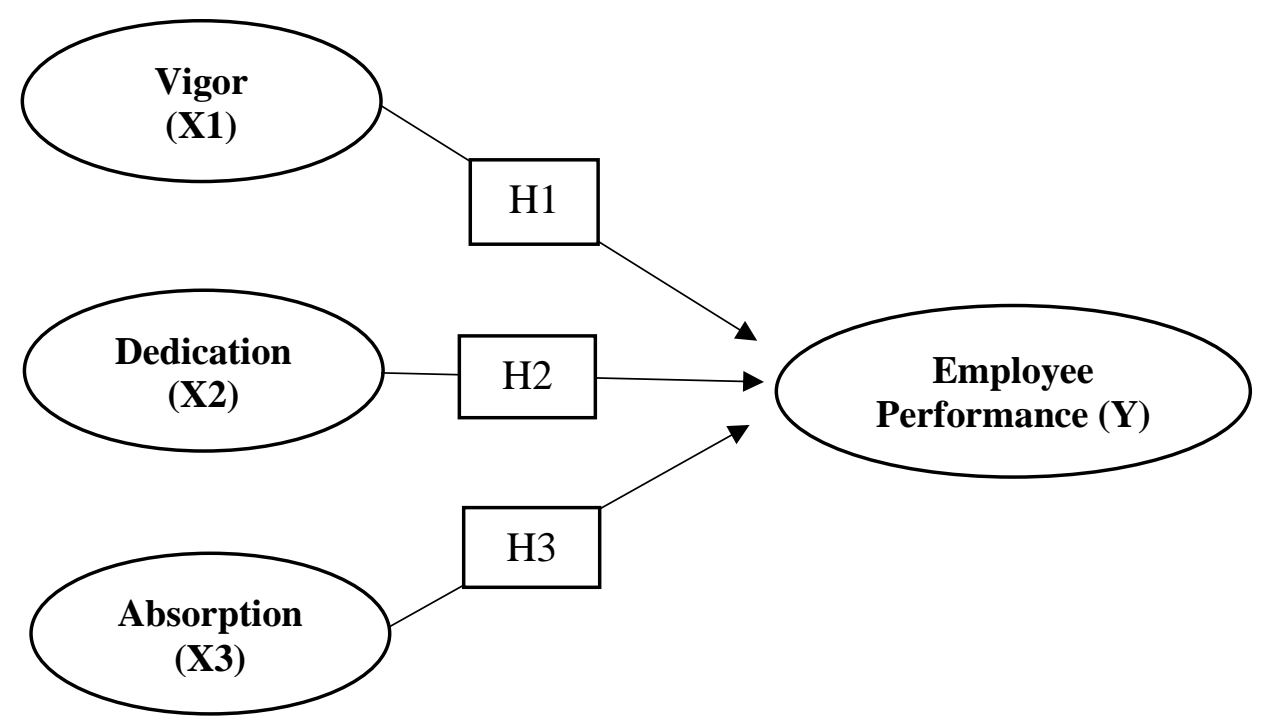

Figure 1. Conceptual Research Model

\section{RESEARCH METHODS}

This research aims to investigate the affect between the construct variables, namely vigor, dedication, and absorption towards employee performance. This research was conducted in September 2020 and took the entire PT. Mandiri Utama Finance's Employees as population. The company's address is in Menara Mandiri Building 1, 27th floor, Jl. Jend. Sudirman Kav.5455 South Jakarta with the total employee population is 210 people. Because the population is relatively small, all employee members are used becomes respondents in this research and it's often called as saturated sampling. Primary data collection was carried out by distributing questionnaire instruments online to all employees in the company.

Vigor variable was measured through 6 questionnaire items. Each questionnaire was designed using 5 Likert closed to the answer choices, which were then converted into scores. The answer category value for strongly agree $=1$, agree $=2$, quite agree $=3$, disagree $=4$, and strongly disagree $=5$. The dedication variable is measured through 5 questionnaire items. Each questionnaire was designed using 5 Likert closed answer choices which were then converted into scores. The answer category value for strongly agrees $=1$, agree $=2$, quite agree $=3$, disagree $=4$, and strongly disagree $=5$. The absorption variable is measured through 6 questionnaire items. Each questionnaire was designed using 5 Likert closed to the answer choices which were then converted into scores. The answer category values for strongly agree $=$ 1 , agree $=2$, quite agree $=3$, disagree $=4$, and strongly disagree $=5$. Performance variables are measured through 4 dimensions: task performance, contextual performance, adaptive performance, and counterproductive work behaviour. The measurement used 22 questionnaire items with 5 Likert closed to choices which were then converted into scores. The value of the answer category for task performance, contextual performance, adaptive performance is strongly disagree $=1$, disagree $=2$, quite agree $=3$, agree $=4$, and strongly agree $=5$, while for the category value for the answer category of counterproductive work behavior is strongly agree $=1$, agree $=2$, quite agree $=3$, disagree $=4$, and strongly disagree $=5$.

These type of research were included in quantitative research with descriptive and confirmatory analysis methods. The descriptive data analysis used simple average statistical techniques, standard deviation, correlation and data presentation with tables. Confirmatory analysis is intended to examind the research hypothesis using multiple linear regression 
analysis and the coefficient of determination. This analysis model was curious about the amount of the influence from vigor, dedication, and absorption towards employee performance.

\section{RESULT AND DISCUSSION Respondent Characteristics}

Members from these researchpopulation were 210 people. All questionnaire entries were returned through online. Respondent profiles according to gender were 91 male $(43.3 \%)$ and 119 female $(56.7 \%)$ based on age were $22-<25$ years was 34 people $(16.2 \%)$, > 25 - 30 years was 79 people $(37.6 \%)$,> 30-35 years was 67 people (31.9\%),> 35was 30 people (14.3\%). The profile of respondents according to education is diploma 48 people (22.9\%), undergraduate 157 people $(74.8 \%)$, post graduate 5 people $(2.4 \%)$.Profiles of respondents according to length of work are 178 people $(84.8 \%)$, more than 5 years 32 people $(15.2 \%)$.

\section{Validity and Reliability Test}

The data processing through SPSS version 25. The results of data processing for validity and reliability tests are shown in Table 2.

Table 2. Test Results for the Validity and Reliability from the Research Questionnaire Instrument

\begin{tabular}{lccc}
\hline \multicolumn{1}{c}{ Variable } & r-count & r-table & Cronbach's Alpha \\
\hline Vigor (X1) & $0,345-0,735$ & 0,135 & 0,618 \\
Dedication (X2) & $0,496-0,765$ & 0,135 & 0,639 \\
Absorption (X3) & $0,578-0,809$ & 0,135 & 0,733 \\
Employee Performance (Y) & $0,176-0,735$ & 0,135 & 0,832 \\
\hline
\end{tabular}

The vigor variable consists of 6 statements with the calculated $r$ value ranging from 0.345 to 0.735 . The dedication variable consists of 5 statements with the calculated $r$ value ranging from 0.496 to 0.765 . The absorption variable consists of 6 statements with the calculated of $r$ value ranging from 0.578 to 0.809 with an r-table value was 0.135 . The performance variable consists of 21 statements, with the calculated $r$ value ranging from 0.176 to 0.735 . And each of variable has an r-table value of 0.135 , thus it can be concluded that all items used to measure the vigor, dedication, absorption, and performance variables were valid. Meaning that the measured instruments regarding vigor, dedication, absorption and performance are capable to achieve the expected measurement goals precisely and able to provide measurement results regarding the vigor, dedication, absorption, and performance variables.

The reliability test result shows that all indicators used to stated the four variables, namely vigor, dedication, absorption and employee performance were reliable because they have a Cronbach alpha value which greater than 0.6 .The vigor variable was 0.618 , the dedication variable was 0.639 , the absorption variable was 0.733 and the employee performance variable was 0.832 .This shows that each statement item from these four variables that used in this research were able to gathered theconsistent data, which means that if the statement is resubmitted again, the answer would relatively the same as the previous ones.

\section{Classic Assumption Test}

Based on the data processed results, it could be seen that the sig. The 2-tailed independent variable (Vigor, Dedication and Absorption) and also the dependent variable (Performance) 
were valued at 0.092 which greater than 0.05 . Then this illustrated that the data was normally distributed.

From these multicollinearity test results, it is known that the tolerance value for Vigor was 0.512, Dedication was 0.511 and Absorption was 0.508. Meanwhile, Vigor VIF value was 1.953, Dedication was 1.958 and Absorption was 1.968. Because all tolerance values were above 0.1 and all VIF values were below 10, so it could be explained that there is no multicollinearity occured.

Based on the heteroscedasticity test results through the Scatterplot, the data spreads in all directions and did not formed any pattern and was illustrated that the data is free from heteroscedasticity. Then it could be interpreted that the data tested were free from heteroscedasticity assumptions and still could used for further analysis.

\section{Multiple Linear Regression Analysis}

Multiple linear regression model used to describe the influence from the independent variables on the dependent variable by creating multiple linear regression line equations. Multiple linear regression analysis in this research was carried out to revealed the affect from vigor, dedication and absorption on employee performance.

Table 3. Multiple Linear Regression Test Results

\begin{tabular}{clrrrrr}
\hline \multicolumn{7}{c}{ Coefficients $^{\mathbf{a}}$} \\
\hline \multirow{2}{*}{ Model } & & \multicolumn{2}{c}{$\begin{array}{c}\text { Unstandardized } \\
\text { Coefficients }\end{array}$} & $\begin{array}{l}\text { Standardized } \\
\text { Coefficients }\end{array}$ & \\
\cline { 3 - 7 } & & $\mathrm{B}$ & Std. Error & $\mathrm{B}$ & $\mathrm{t}$ & \multicolumn{1}{c}{ Sig. } \\
\hline & (Constant) & 2,068 & .190 & & 10,896 & .000 \\
& Vigor & .137 & .062 & .176 & 2,206 & .028 \\
& Dedication & .194 & .056 & .274 & 3,434 & .001 \\
& Absorption & .150 & .057 & .212 & 2,655 & .009 \\
\hline
\end{tabular}

a. Dependent Variabel: Employee Performace

Based on Table 3 , the regression model Y obtained $=2.068+0.137 \mathrm{X} 1+0.194 \mathrm{X} 2+$ $0.150 X 3$. According to the regression model above, it could be seen that the vigor, dedication and absorption variables have a positive affect on employee performance. The regression coefficient $\left(\beta_{1}\right)$ of vigor variable was 0.137 with t-count was 2.206 and t-table was 1.652 with significance of 0.028 . The conclusion was that the vigor variable is a good and strong predictor for discovering the ups and downs of performance and its weak affect. This illustrated that vigor variable has a positive and significant affect on performance then the Hypothesis 1 wass accepted.

The regression coefficient $\left(\beta_{2}\right)$ of the dedication variable was 0.194 with $t$-count of 3.750 with t-table was 3.434 with significance value of 0.001 . The conclusion is that the dedication variable is a good and strong predictor to discovering the fluctuate of performance and its weak affect. This illustrated that the dedication variable has a significant affect on performance then the Hypothesis 2 was accepted.

The regression coefficient $\left(\beta_{3}\right)$ of the absorption variable was 0.150 with tcount was 2.65 with t-table was 1.652 andwith significance of 0.009 . The conclusion is absorption variable is a good and strong predictor to revealed the fluctuate of performance and its weak affects. This illustrated that the absorption variable has a significant affect on performance so the Hypothesis 3 was accepted. 


\section{Coefficient of Determination Test $\left(\mathbf{R}^{2}\right)$}

The coefficient of determination test was carried out to find out how much the ability of the independent variable explained the dependent variable.

Table 4. The R-Square Coefficient of Determination Results

\begin{tabular}{|c|c|c|c|c|}
\hline \multicolumn{5}{|c|}{ Model Summary } \\
\hline Model & $\mathrm{R}$ & R Square & Adjusted R Square & $\begin{array}{l}\text { Std. Error of the } \\
\text { Estimate }\end{array}$ \\
\hline 1 & $.576^{\mathrm{a}}$ & .332 & .322 & .28554 \\
\hline
\end{tabular}

According to the Table 4, it is known that the R-Square value $=0.332$. However, for the number of independent variables which more than two, it would be better to use an Adjusted $\mathrm{R}$ square, which is 0.322 (always smaller than the R square). This shows that $32 \%$ of performance (Y) was influenced by the Vigor variable (X1), Dedication (X2) and Absorption variable (X3) while the lastremaining of $68 \%$ was influenced by the other factors outside of this research model.

\section{Discussion}

According to the results from this research all hypothesis could be accepted. Hypothesis 1 which explained that the vigor variable has a positive and significant affect on the employee performance at PT. Mandiri Utama Finance. Meaning that the vigor variable is a predictor which could improve the employee performance. The employees' sense of attachment shown through physical and mental strength when doing work which turns out to be able in maximizing the employee performance. This is marked by the high level of mental strength at work for each employee, the presence of optimal energy, the courage to do everything that they can, the desire and willingness to put serious effort in order to provide the maximum results in any given tasks. These research results were in line with the results from Jaya \& Dawood (2020) which stated that vigor has a positive and significant affect on employee performance at IT companies in Chennai. Likewise, to the research results from Carter et al. (2016) which illustrated that vigor has a positive and significant affect on performance. While the research results from Winowoda (2018) were explained those similiar thing that said if this vigor has a significant affect on employee performance.

These research results was indicate that the higher the vigor, the higher the employees' performance would be. Conversely, if the lower the vigor, the employees' performance would be lower aswell. The Employees who have a high spirit of enthusiasm in doing work tends to be able to increase their performance better. The large energy level owned by the employees of PT. Mandiri Utama Finance would inspires them to continue to provide an optimal performance. Persistence and perseverance which shown by employees at the company are due to in form of responsibility which makes them try to be able to complete their work. The existence of good teamwork is also one of factor from employees in capable to achieve the optimal performance. Conversely, without good teamwork it would lead to the work failure, disappointment, low morale and also less productivity which become threatens to the organizational entity (Nurhayati et al., 2018).

Dedication is an enthusiastic feeling which employees felt when worked, proud of the work done and the company that they work for, staying inspired and diligent to the end at the company without feeling threatened by the challenges that they face. According to the research 
results was indicated that dedicaton has a positive and significant affect towards the employees performance at PT. Mandiri Utama Finance. Meaning that the dedication variable is a strong predictor for improving the employee performance. This characterized by enthusiasm for the work they do, having meaningful, inspiring and challenging experiences and being proud of the work and the company that they work for. These research results were in line with the results from Fauzi \& Ed (2016) which stated that dedication has a positive and significant affect towards the employee performance and has a high contribution. Likewise, to the Fan \& Cai's research (2017) shows that dedication has a positive and significant affect towards task performance and contextual performance. While the research results from Al-dalahmeh et al. (2018) were explained that the dedication is significantly contributes to the employee performance.

The existence of the PT. Mandiri Utama Finance, which is one of the subsidiaries from the largest bank in Indonesia, namely Bank Mandiri and has become part of the Mandiri Group, would be able to make employees feel proud of the work they do, thus motivating employees in improve their performance. Besides, the high desire of employees to do their jobs with meaning and purpose it could be a factor which encourage the employees to improve their performance. This is supported by data on the characteristics of the research respondents, the majority are millennials with an age range of 22 years - 30 years, as many as 113 respondents. One of the characteristics of these millennials is that they would feel challenged by work environment which involves with creativity and transform. They do not like anything static for long periods of time and always trying to find ways to increase the productivity and efficiency.

Absorption is an employees' attachment which shown by giving full attention to their job. According to the research results, it shows that absorption has a positive and significant affect on employee performance at PT. Mandiri Utama Finance. Meaning that the absorption variable is a predictor which could improve the employee performance. This indicated by the employees' pleasure when they are totally immersed on their works and feels that time flies so fast which they finds it difficult to let go or separate themselves from work. The research results were in line with the results from Lewiuci et al.(2016) stated that absorption partially has a positive and significant affect on employee performance and has a high contribution effect. Likewise, to the research results from Meilia \& Setyowati (2016) showed that absorption has a positive and significant affect on performance. Meanwhile, the research results which conducted by Meswantri \& Awaludin (2018) explained that absorption has significantly contributed to employee performance.

These research results was indicate that the higher the absorption, the higher the employees' performance would be. Likewise, if the lower the absorption, the lower employee performance would earned. The employees who give full attention to their work by trying to highly concentrate and focus in doing every job so the time would passes so quickly and they find it difficult to get away from work which could affect to the fluctuate of employee performance. When working hours have finished the employees at PT. Mandiri Utama Finance still doing their good job where they suppose to return to home. It's not all because of their unfinished work so it takes more time to do it. But they feel enjoy the work they do, so they would find it difficult to get away from their work and they even feel the time is running so fast. It is also marked by the sense of comfort felt by employees due to the team work between colleagues that goes well with one another and a sense of kindred which is established in their work environment. 


\section{CONCLUSION AND SUGGESTION Conclusion}

From these hypothesis test results, it was proved that vigor has a positive and significant affect on employee performance (H1), dedication has a positive and significant affect on employee performance $(\mathrm{H} 2)$ and absorption has a positive and significant affect on employee performance (H3).All hypothesis have a very weak positive affect through coefficient of determination (R2) which only $32 \%$.The amount of this coefficient was relatively small, so it can be interpreted that vigor, dedication and absorption are low predictors to increase the performance at PT. Mandiri Utama Finance.

\section{Suggestion}

Based on the conclusions from the research results and discussion that have been described previously, the authors put forward some suggestions as follows:

1) The Companies should carry out appropriate training or knowledge sharing then each employee could learn to understand each other's work in the company. The training needs to create more weighty and more effective and efficient so it could be learned by all employees, especially for some jobs that require a special skills or expertise.

2) The companies should make an improvements on methods and parameters in appraising and evaluating employee performance so the individual performance could be evaluated properly as a whole. Through the right measurement, the employees would be more encourage to improve their performance because the process is considered transparent and fair. Appropriate performance appraisal would helps the management to find the best talent for the company.

3) The companies should establish an appreciation, recognition and inspiration for employees. Giving employee appreciation is very important in order to create positive behavior and enthusiasm for employees to excel the job. Recognition of achievements that reached by employees in the workplace, rewards given for the success of employees in achieving the company targets or rewards for attendance and discipline those are an appreciation for the achievements that could be felt by employees. Inspiration that earned from each leader in which there has a vision and mission of the company that should be clearly explained by each employee so they would become enthusias and passionate about their work so as to push their performance optimally.

4) Considering the company's goal is to earn profits and achieve the maximum possible target, then it needs to have a role model from the leaders. A good leader would capable to bring the team to the maximum performance results.

5) Company culture is very influential in the internal environment of the company, so it is necessary to create a safe, comfortable and family atmosphere in it. Creating a productive work environment is not that easy. It needs direct contribution from each team member so that comfortable and pleasant work atmosphere could be created by itself. This needs to be taken into consideration by company leaders in view that a conducive work environment will be able to encourage each member to accomplish their work properly.

6) It is expected that PT. Mandiri Utama Finance will conduct further research studies to search other factors that are expected to have strong impact towards employee performance then it would become a reference for management in effort on further improvement.

7) The expectation from the authors for further research is that they could further investigate related to other variables outside this research variables, both internally related to personal such as motivation and work discipline and those external factors related to the company and its environment such as organizational culture, training, compensation, leadership and etc. Future research also need to use a variety methods as a research analysis tool. 


\section{REFERENCES}

Al-dalahmeh, M., Khalaf, R., \& Obeidat, B. (2018). The effect of employee engagement on organizational performance via the mediating role of job satisfaction: The case of IT employees in Jordanian banking sector. Modern Applied Science, 12(6), 17-43.

Al-dalahmeh, M., Masa'deh, R., Khalaf, R. K. A., \& Obeidat, B. Y. (2018). The Effect of Employee Engagement on Organizational Performance Via the Mediating Role of Job Satisfaction: The Case of IT Employees in Jordanian Banking Sector. Journal of Modern Applied Science, 12(6), 17-43. https://doi.org/10.5539/mas.v12n6p17

Bilal, D. H., Khan, A. A., Khan, K. A., \& Shah, D. S. N. (2019). The Impact of Employee Engagement on Task Performance. Journal of Business and Tourism, 04 No. 2(July), 135141.

Carter, W. R., Nesbit, P. L., Carter, W. R., Nesbit, P. L., Badham, R. J., \& Parker, S. K. (2016). The effects of employee engagement and self- efficacy on job performance : a longitudinal field study. The International Journal of Human Resource Management, February 2018, 0. https://doi.org/10.1080/09585192.2016.1244096

Edison, Anwar, \& Komariyah. (2016). Manajemen Sumber Daya Manusia. Alfabeta.

Fan, H., \& Cai, D. (2017). Employee Engagement and Job Performance of Employees - a Study from Hospitality and Tourism in Hainan. 2nd International Conference on Education, E-Learning and Management Technology (EEMT 2017), Eemt, 586-591.

Fauzi, O. F., \& Ed, J. S. M. (2016). Pengaruh Employee Engagement Terhadap Kinerja Karyawan Di Pt Studio Cilaki Empat Lima Bandung. 3(3), 3080-3087.

Gil, E., Llorens, S., \& Salanova, M. (2020). Employees' Physical Exercise, Resources, Engagement, and Performance: A Cross-sectional Study from HERO Model. Journal of Work and Organizational Psychology, 1-9. https://journals.copmadrid.org/jwop

Hanaysha, J. (2016). Improving employee productivity through work engagement: Empirical evidence from higher education sector. Management Science Letters, 6, 61-70. https://doi.org/10.5267/j.msl.2015.11.006

Javed, F., \& Cheema, S. (2015). The Relationship Between Organizational Resources and Work Engagement: The Mediating Role of Service Climate as a Predictor of Performance and Loyalty in Shopping Malls of Pakistan. Journal of Business Studies Quarterly, 7(2), $11-22$.

Jaya, S., \& Dawood, D. D. A. K. (2020). Employee Engagement And Its Impact On Organizational Performance (A Study With Reference To It Companies, Chennai). Science, Technology and Development, IX(I), 278-285.

Joushan, S. A., Syamsun, M., \& Kartika, L. (2015). Pengaruh Budaya Organisasi dan Employee Engagement terhadap Kinerja Karyawan pada PT PLN ( Persero ) Area Bekasi. Jurnal Aplikasi Manajemen (JAM), 13(66), 697-703.

Lewiuci, P. G., Mustamu, R. H., Bisnis, P. M., Manajemen, P. S., Petra, U. K., \& Siwalankerto, J. (2016). Pengaruh Employee Engagement Terhadap Kinerja Karyawan Produsen Senapan Angin. AGORA, 4(2), 101-107. 
Mahadika, C., Hadi, M. A., \& Prodi Studi Manajemen, Fakultas Ekonomi, U. R. K. (2018). Pengaruh Keterlibatan Karyawan, Lingkungan Kerja Dan Budaya Perusahaan Terhadap Kinerja Karyawan Pada PT. Jolin Permata Buana Kota Batam. Jurnal Equilibiria, 5(1), $51-63$.

Mangkunegara, A. A. A. P. (2016). Manajemen Sumber Daya Manusia Perusahaan. Remaja Rosdakarya.

Meilia, C. H. P., \& Setyowati, W. (2016). Pengaruh Modal Psikologi Dan Peran Keterlibatan Karyawan Terhadap Kinerja Pegawai Dengan Mediasi Komitmen Organisasional (Studi Pada Lembaga Penjaminan Mutu Pendidikan Provinsi Jawa Tengah). Telaah Manajemen, $13,45-55$.

Meswantri, M., \& Awaludin, A. (2018). Determinant of Employee Engagement and its Implications on Employee Performance. Econ Journals, International Review of Management and Marketing, 8(3), 36-44. http: www.econjournals.com

Natrajan, N. S., Sanjeev, R., \& Singh, S. K. (2019). Achieving Job Performance From Empowerment Through The Mediation Of Employee Engagement: An Empirical Study. INDEPENDENT JOURNAL OF MANAGEMENT \& PRODUCTION (IJM\&P), 10(June), 1094-1105. https://doi.org/10.14807/ijmp.v10i3.891

Nawangsari, L. C., \& Sutawidjaya, A. H. (2019). Talent management in mediating competencies and motivation to improve employee's engagement. International Journal of Economics and Business Administration, 7(1), 140-152. https://doi.org/10.35808/ijeba/201

Nurhayati, M., Pramudito, O., \& Ermawati, E. (2018). The Importance of Teamwork on Business Restaurant in Medicating Effect of Work Discipline on Employee Performance. European Journal of Business and Management, 10(18), 42-50.

Produk Pembiayaan. (2020). Https://Www.Muf.Co.Id/. https://www.muf.co.id/produkpembiayaan/

Puspa, D. M., \& Sagala, E. J. (2018). Pengaruh Employee Engagement Dan Komitmen Karyawan Terhadap Kinerja Karyawan Bank Generasi Y ( Studi Pada Bank Bri Kabupaten Wonosobo ). Jurnal Manajemen, 15(2), 181-194.

Robbins, S. P., \& Coulter, M. (2010). Manajemen (10th ed.). Erlangga.

Rustono, A., \& Akbary, M. F. (2015). Pengaruh Employee Engagement Terhadap Kinerja Karyawan Dana Pensiun ( Dapen ) Telkom Bandung. E-Proceeding of Management, 2(2), $1172-1178$.

Schaufeli, W. B., \& Bakker, A. B. (2004). Utrecht work engagement scale Preliminary Manual Version 1.1. Occupational Health Psychology Unit Utrecht University, December, 1-60. https://doi.org/10.1037/t01350-000

Winowoda, D. A. (2018). Pengaruh Employee Engagement dan Kepuasan Kerja terhadap Kinerja Karyawan Melalui Komitmen Organisasi Sebagai Variabel Intervening di Hotel Grand Inna Malioboro Yogyakarta. 4-21. https://dspace.uii.ac.id/handle/123456789/8035

Witasari, J., \& Gustomo, A. (2020). Understanding The Effect of Human Capital Management Practices , Psychological Capital, and Employee Engagement To Employee Performances. The Asian Journal of Technology Management, 13(1), 1-15. 
https://doi.org/http://dx.doi.org/10.12695/ajtm.2020.13.1.1

Yin, N. (2017). The Effect of Job Engagement on Job Burnout and Job Performance: The Moderating Effect of Organizational Justice. International Journal of Business and Management, 12(5), 177-191. https://doi.org/10.5539/ijbm.v12n5p177 